\title{
Iridium-Promoted B-B Bond Activation: Preparation and X-ray Diffraction Analysis of a mer-Tris(boryl) Complex
}

\author{
Miguel A. Esteruelas, ${ }^{*}{ }^{\dagger}$ Israel Fernández, ${ }^{\ddagger}$ Antonio Martínez, ${ }^{\dagger}$ Montserrat Oliván, ${ }^{\dagger}$ \\ Enrique Oñate, ${ }^{\dagger \oplus}$ and Andrea Vélez ${ }^{\dagger}$ \\ †Departamento de Química Inorgánica, Instituto de Síntesis Química y Catálisis Homogénea (ISQCH), Centro de Innovación en \\ Química Avanzada (ORFEO-CINQA), Universidad de Zaragoza-CSIC, 50009 Zaragoza, Spain \\ †Departamento de Química Orgánica I, Facultad de Ciencias Químicas, Centro de Innovación en Química Avanzada \\ (ORFEO-CINQA), Universidad Complutense de Madrid, 28040 Madrid, Spain
}

Supporting Information

ABSTRACT: The tris(boryl) complex $\operatorname{Ir}(\text { Bcat })_{3}\left\{\kappa^{3}-\right.$ $\left.\mathrm{P}, \mathrm{O}, \mathrm{P}-\left[\operatorname{xant}\left(\mathrm{P}^{\mathrm{i}} \mathrm{Pr}_{2}\right)_{2}\right]\right\}\left[\right.$ Bcat $=$ catecholboryl; $\operatorname{xant}\left(\mathrm{P}^{\mathrm{i}} \mathrm{Pr}_{2}\right)_{2}$ = 9,9-dimethyl-4,5-bis(diisopropylphosphino)xanthene has been prepared and characterized by X-ray diffraction analysis. The boryl ligands are disposed in a mer arrangement. The $\mathrm{Ir}-\mathrm{B}$ bonds situated mutually trans are $\sim 0.1 \AA$ longer than that disposed cis to the other two. An energy decomposition analysis method coupled to natural orbitals for chemical valence has revealed that the level of $\pi$-back-donation from the metal to the $\mathrm{p}_{z}$ atomic orbital of the boron atom decreases $\sim 43 \%$ in the longer bonds with respect to the shorter one, while the level of $\sigma$ bonding interaction diminishes by only $\sim 8 \%$.

D idcock, Richards, and Venanzi defined trans influence, in 1966, as "the tendency of a ligand to weaken the bond trans to itself". It is therefore a thermodynamic concept, which has a noticeable effect on the bond lengths ${ }^{2}$ and stability of the coordination compounds. ${ }^{3}$ Two ligands with a strong trans influence destabilize the complex, when they are situated mutually trans. A strong trans influence is characteristic of strong $\sigma$-donating ligands, ${ }^{4}$ whereas an inverse relation between the trans influence of a ligand and its electronegativity exists. ${ }^{5}$ Pauli repulsion causes the weakening of the bond trans to a good $\sigma$-donor ligand. Donated electron density accumulates on the trans site of the metal. As a consequence, the ligand at this position undergoes repulsion of the resulting electron cloud. The process can be envisioned as the donation from the trans ligand to the $\sigma^{*}$ orbital of the metal-ligand bond trans to it. ${ }^{6}$

Boryl groups, with a $\mathrm{sp}^{2}$-hybridized boron atom bearing an "empty" $\pi$-orbital, are among the strongest trans influence ligands because of their strong $\sigma$-donor character and as a consequence of the electropositive nature of boron. ${ }^{7}$ Overwhelming evidence of this is the fact that in all transition metal complexes characterized by X-ray diffraction analysis, with two $^{8}$ or three 9 boryl ligands, they systematically occupy mutually cis or fac positions, respectively, avoiding the mutually trans disposition of two of them. In contrast, a few posttransition element-bis(boryl) compounds with a linear rearrangement have been reported. ${ }^{10}$
Pincer ligands develop marked abilities to stabilize less common coordination polyhedra due to the disposition of their donor atoms . 9,9-Dimethyl-4,5-bis (diisopropylphosphino)xanthene $\left[\operatorname{xant}\left(\mathrm{P}^{\mathrm{i}} \mathrm{Pr}_{2}\right)_{2}\right]$ is a neutral diphosphine, which has been demonstrated to be more able than other ether diphosphines, such as 9,9-dimethyl-4,5bis(diphenylphosphino)xanthene $\left[\operatorname{xant}\left(\mathrm{PPh}_{2}\right)_{2}\right]^{11}$ or bis $[(2-$ diphenylphosphino)phenyl] ether (DPEphos), ${ }^{12}$ to act as a pincer ligand, ${ }^{13}$ although a few compounds with the diphosphine coordinated as bidentated or fac have been also isolated. ${ }^{14}$ This Communication reveals that the diphosphine $\operatorname{xant}\left(\mathrm{P}^{\mathrm{i}} \mathrm{Pr}_{2}\right)_{2}$ also has the capacity to stabilize transition metal complexes with two boryl groups disposed mutually trans. By using its noticeable ability to coordinate mer and its neutral character, we have been able to prepare and to fully characterize an iridium(III) complex bearing three boryl ligands having a mer disposition.

The complex was prepared according to Scheme 1. Complex $\operatorname{IrHCl}\left\{\kappa^{4}-\mathrm{C}, \mathrm{P}, \mathrm{O}, \mathrm{P}-\left[\mathrm{CH}_{2} \mathrm{CH}\left(\mathrm{CH}_{3}\right) \mathrm{P}\left({ }^{\mathrm{i}} \mathrm{Pr}\right) \operatorname{xant}\left(\mathrm{P}^{\mathrm{i}} \mathrm{Pr}_{2}\right)\right]\right\} \quad(\mathbf{1}$ in path $\mathrm{a})^{13 \mathrm{~b}}$ is a synthetic equivalent of the square-planar species $\operatorname{IrCl}\left\{\kappa^{3}-\mathrm{P}, \mathrm{O}, \mathrm{P}-\left[\operatorname{xant}\left(\mathrm{P}^{\mathrm{i}} \mathrm{Pr}_{2}\right)_{2}\right]\right\} \quad(\mathbf{1 a})$, the iridium counterpart of $\operatorname{RhCl}\left\{\kappa^{3}-\mathrm{P}, \mathrm{O}, \mathrm{P}-\left[\operatorname{xant}\left(\mathrm{P}^{\mathrm{i}} \mathrm{Pr}_{2}\right)_{2}\right]\right\}$. Like the latter, complex la has a marked ability to activate $\sigma$-bonds, ${ }^{13 c}$ including $\mathrm{B}-\mathrm{B}$ bonds. Thus, the treatment of toluene solutions of 1 with 3.0 equiv of bis(catecholato)diboron $\left(B_{2} \mathrm{cat}_{2}\right)$, at room temperature, for $15 \mathrm{~min}$ gives rise to the quantitative formation of $\operatorname{Ir}(\mathrm{Bcat})_{3}\left\{\kappa^{3}-\mathrm{P}, \mathrm{O}, \mathrm{P}-\left[\operatorname{xant}\left(\mathrm{P}^{\mathrm{i}} \mathrm{Pr}_{2}\right)_{2}\right]\right\} \quad$ (2) and ClBcat, as a result of the $\mathrm{B}-\mathrm{B}$ bond activation of two molecules of diborane. The process most probably occurs via the intermediates $\operatorname{IrCl}(\mathrm{Bcat})_{2}\left\{\kappa^{3}-\mathrm{P}, \mathrm{O}, \mathrm{P}-\left[\operatorname{xant}\left(\mathrm{P}^{\mathrm{i}} \mathrm{Pr}_{2}\right)_{2}\right]\right\}$ (A) and $\operatorname{Ir}(\mathrm{Bcat})\left\{\kappa^{3}-\mathrm{P}, \mathrm{O}, \mathrm{P}-\left[\operatorname{xant}\left(\mathrm{P}^{\mathrm{i}} \mathrm{Pr}_{2}\right)_{2}\right]\right\}(\mathrm{B})$. Attempts to detect them were unsuccessful because the oxidative addition of the diborane to $\mathbf{1} \mathbf{a}$ and $\mathbf{B}$ and the reductive elimination of $\mathrm{ClBcat}$ from $\mathbf{A}$ appear to be very fast and the formation of $\mathbf{2}$ is strongly favored; even the addition of 1.0 equiv of diborane to 1 exclusively gives $\mathbf{2}$ in $50 \%$ yield.

The white complex 2 was characterized by X-ray diffraction analysis. The structure (Figure 1) confirmed the mer disposition of the boryl groups. The resulting octahedron displays $\mathrm{P}(1)-\mathrm{Ir}-\mathrm{P}(1 \mathrm{~A}), \mathrm{B}(1)-\mathrm{Ir}-\mathrm{B}(1 \mathrm{~A})$, and $\mathrm{O}(1)-\mathrm{Ir}-$

Received: February 4, 2019 
Scheme 1. Pathways for the Formation of 2

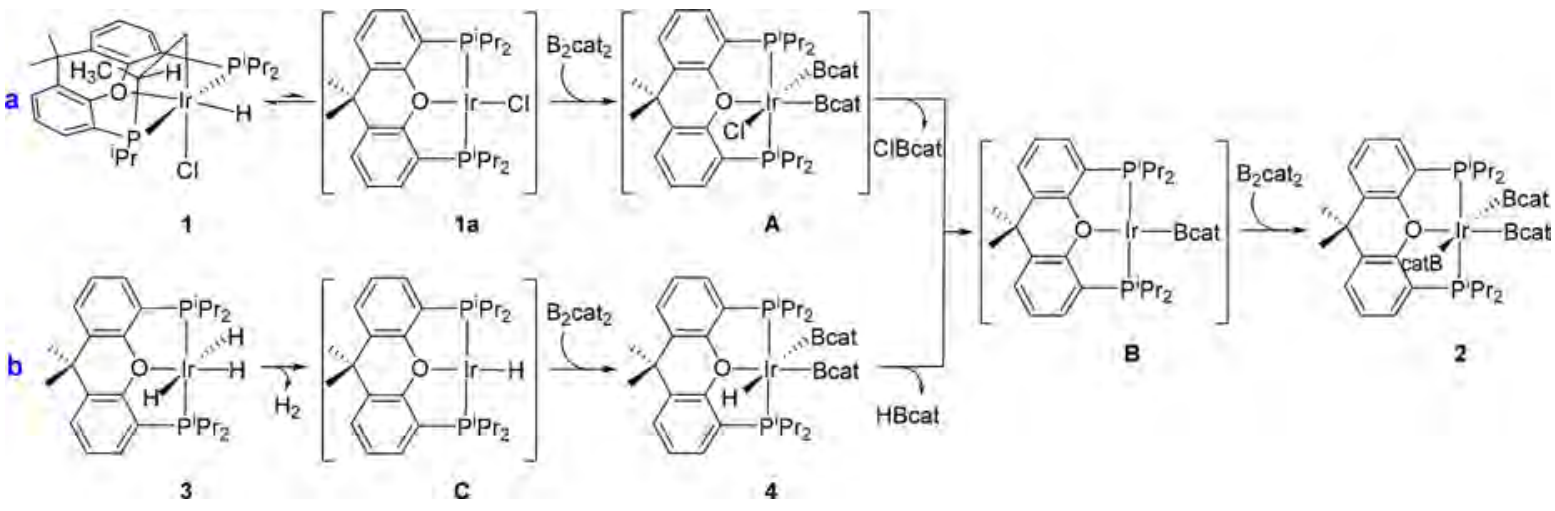

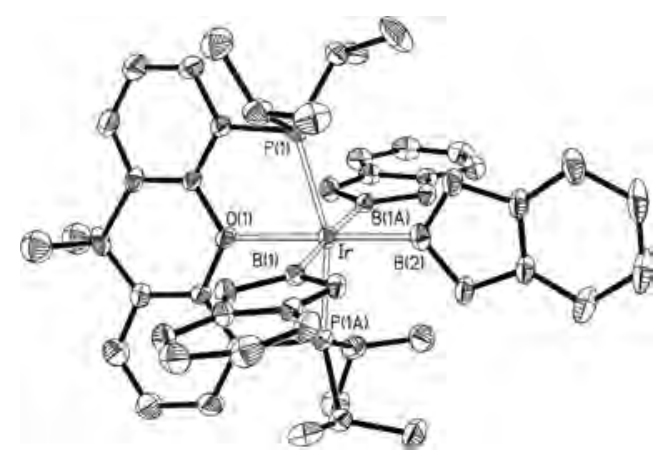

Figure 1. Molecular diagram of complex 2. Hydrogen atoms have been omitted for the sake of clarity.

$\mathrm{B}(2)$ angles of $160.49(8)^{\circ}, 175.2(4)^{\circ}$, and $180.000(2)^{\circ}$, respectively. The iridium-boron bond lengths of 2.124(7) $\AA$ $[\operatorname{Ir}-\mathrm{B}(1)$ and $\operatorname{Ir}-\mathrm{B}(1 \mathrm{~A})]$ and $2.012(10) \AA[\operatorname{Ir}-\mathrm{B}(2)]$ are consistent with the strong trans influence of the boryl ligands. Thus, the $\operatorname{Ir}-\mathrm{B}(1)$ and $\operatorname{Ir}-\mathrm{B}(1 \mathrm{~A})$ bonds, which lie disposed mutually trans, are significantly longer $(0.1 \AA)$ than the Ir$\mathrm{B}(2)$ bond. In agreement with the structure, the ${ }^{31} \mathrm{P}\left\{{ }^{1} \mathrm{H}\right\}$ nuclear magnetic resonance (NMR) spectrum shows a singlet for the equivalent $\mathrm{P}^{\mathrm{i}} \mathrm{Pr}_{2}$ groups. The ${ }^{11} \mathrm{~B}\left\{{ }^{1} \mathrm{H}\right\}$ NMR spectrum contains a broad signal centered at $\sim 33 \mathrm{ppm}$ due to the three boryl groups.

The Ir-B bonds of 2 were analyzed by means of the energy decomposition analysis method coupled to natural orbitals of chemical valence (EDA-NOCV). ${ }^{15}$ To this end, we explored the nature of both $\mathrm{Ir}-\mathrm{B}(2)$ and $\mathrm{Ir}-\mathrm{B}(1)$ bonds. The fragments were calculated either in their doublet state, which leads to an electron-sharing single bond, or in their electronic singlet state, using charged fragments, which provides a dative $\operatorname{Ir} \leftarrow B$ bond. It has been previously shown that the calculation giving the smallest orbital term $\Delta E_{\text {orb }}$ indicates the most faithful description of the type of binding, ${ }^{16}$ because it also shows the smallest change in the electronic structure of the fragments upon bond formation. According to the data in Table 1, it becomes evident that the chemical bond between the [Ir] and [B] fragments is better described as a covalent (i.e., electronsharing) $\sigma$-single bond. Further inspection of the EDA data reveals that the major contribution to the total interaction in both $\mathrm{Ir}-\mathrm{B}$ bonds comes from the electrostatic term $\Delta E_{\text {elstat }}$ which contributes $\sim 56-58 \%$ to $\Delta E_{\text {int }}$. This is not surprising due to the higher electronegativity of the iridium atom that polarizes the $\mathrm{Ir}-\mathrm{B}$ bond. ${ }^{17}$ In agreement with this, the metal center supports a negative charge of -0.40 , while the boron
Table 1. EDA-NOCV Results (in kilocalories per mole) Computed at the ZORA-BP86-D3/TZ2P+//BP86-D3/def2TZVPP Level

\begin{tabular}{|c|c|c|c|c|}
\hline & \multicolumn{2}{|c|}{$\mathrm{Ir}-\mathrm{B}(2)$} & \multicolumn{2}{|c|}{$\mathrm{Ir}-\mathrm{B}(1)$} \\
\hline & $\begin{array}{l}\text { electron- } \\
\text { sharing }\end{array}$ & dative bond & $\begin{array}{l}\text { electron- } \\
\text { sharing }\end{array}$ & dative bond \\
\hline & {$[\mathrm{Ir}]^{\bullet}$} & {$[\mathrm{Ir}]^{-}$} & {$[\mathrm{Ir}]^{\bullet}$} & {$[\mathrm{Ir}]^{-}$} \\
\hline & {$[\mathrm{B}]^{\bullet}$} & {$[\mathrm{B}]^{+}$} & {$[\mathrm{B}]^{\bullet}$} & {$[\mathrm{B}]^{+}$} \\
\hline$\Delta E_{\text {int }}$ & -118.0 & -301.2 & -100.8 & -175.5 \\
\hline$\Delta E_{\text {Pauli }}$ & 217.6 & 429.2 & 189.7 & 370.4 \\
\hline$\Delta E_{\text {elstat }}{ }^{a}$ & $\begin{array}{l}-195.4 \\
(58.2 \%)\end{array}$ & $\begin{array}{l}-509.9 \\
(69.8 \%)\end{array}$ & $\begin{array}{l}-163.8 \\
(56.4 \%)\end{array}$ & $\begin{array}{l}-400.6 \\
(73.4 \%)\end{array}$ \\
\hline$\Delta E_{\text {orb }}^{a}$ & $\begin{array}{l}-123.2 \\
(36.7 \%)\end{array}$ & $\begin{array}{l}-203.5 \\
(27.9 \%)\end{array}$ & $\begin{array}{l}-109.0 \\
(37.5 \%)\end{array}$ & $\begin{array}{l}-127.6 \\
(23.4 \%)\end{array}$ \\
\hline$\Delta E_{\text {disp }}^{a}$ & $\begin{array}{l}-17.0 \\
(5.1 \%)\end{array}$ & $\begin{array}{l}-17.0 \\
(2.3 \%)\end{array}$ & $\begin{array}{l}-17.7 \\
(6.1 \%)\end{array}$ & $\begin{array}{l}-17.7 \\
(3.2 \%)\end{array}$ \\
\hline$\Delta E_{\text {orb }}(\sigma)^{b}$ & $\begin{array}{l}-93.0 \\
(75.5 \%)\end{array}$ & $\begin{array}{l}-159.5 \\
(78.4 \%)\end{array}$ & $\begin{array}{l}-86.3 \\
(79.2 \%)\end{array}$ & $\begin{array}{l}-92.4 \\
(72.4 \%)\end{array}$ \\
\hline$\Delta E_{\mathrm{orb}}(\pi)^{b}$ & $\begin{array}{l}-15.5 \\
(12.6 \%)\end{array}$ & $\begin{array}{l}-10.6 \\
(5.2 \%)\end{array}$ & $-8.9(8.1 \%)$ & $-7.3(5.7 \%)$ \\
\hline$\Delta E_{\text {orb }}(\text { rest })^{b}$ & $\begin{array}{l}-14.7 \\
(11.9 \%)\end{array}$ & $\begin{array}{l}-33.4 \\
(16.4 \%)\end{array}$ & $\begin{array}{l}-13.8 \\
(12.7 \%)\end{array}$ & $\begin{array}{l}-27.9 \\
(21.9 \%)\end{array}$ \\
\hline
\end{tabular}

$a_{\text {The values within parentheses indicate the percentage of the total }}$ interaction energy $\left(\Delta E_{\text {int }}=\Delta E_{\text {elstat }}+\Delta E_{\text {orb }}+\Delta E_{\text {disp }}\right)$. ${ }^{b}$ The values in parentheses give the percentage contribution to the total orbital interactions $\Delta E_{\text {orb }}$.

atoms have positive charges of $+0.80[\mathrm{~B}(1)]$ and $+1.06[\mathrm{~B}(2)]$. Interestingly, the partitioning of the $\Delta E_{\text {orb }}$ by means of the NOCV method suggests that, although the $\sigma$-bonding is the main contributor to the $\mathrm{Ir}-\mathrm{B}$ bond $(\sim 76-79 \%)$, there is a significant $\pi$-back-donation from the transition metal fragment to the $\mathrm{p}_{z}$ atomic orbital of the boron atom (Table 1 and Figure 2 ). Strikingly, the computed $\pi$-back-donation is stronger for the $\operatorname{Ir}-\mathrm{B}(2)$ bond than for the $\operatorname{Ir}-\mathrm{B}(1)$ bond, which is nicely consistent with the shorter $\mathrm{Ir}-\mathrm{B}$ distance observed both experimentally and computationally (2.000 $\AA$ vs $2.135 \AA$ )

Complex 2 can be also prepared starting from the trihydride $\mathrm{IrH}_{3}\left\{\kappa^{3}-\mathrm{P}, \mathrm{O}, \mathrm{P}-\left[\operatorname{xant}\left(\mathrm{P}^{\mathrm{i}} \mathrm{Pr}_{2}\right)_{2}\right]\right\} \quad$ (3) and $\mathrm{B}_{2}$ cat $_{2}$ (path $\mathrm{b}$ in Scheme 1) by a procedure similar to that summarized in path a, in agreement with the proven ability of polyhydrides of platinum group metals to activate $\sigma$-bonds. ${ }^{18}$ The key species for its formation is also B. It is now generated via $\operatorname{IrH}\left\{\kappa^{3}\right.$ $\left.\mathrm{P}, \mathrm{O}, \mathrm{P}-\left[\operatorname{xant}\left(\mathrm{P}^{\mathrm{i}} \mathrm{Pr}_{2}\right)_{2}\right]\right\} \quad(\mathrm{C})$ and $\operatorname{IrH}(\mathrm{Bcat})_{2}\left\{\kappa^{3}-\mathrm{P}, \mathrm{O}, \mathrm{P}-[\right.$ xant$\left.\left.\left(\mathrm{P}^{\mathrm{i}} \mathrm{Pr}_{2}\right)_{2}\right]\right\}$ (4), which are the hydride counterparts of the chloride species 1a and $\mathbf{A}$, respectively. However, in this case, intermediate 4 can be detected and even isolated as a pure white solid in $60 \%$ yield when 1.0 equiv of $\mathrm{B}_{2} \mathrm{cat}_{2}$ is employed. 
(a) $\operatorname{Ir}-B(2)$

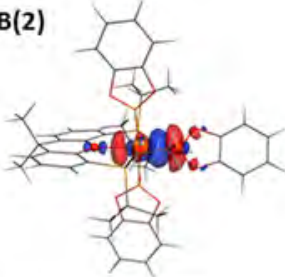

$\Delta E(\sigma)=-93.0 \mathrm{kcal} / \mathrm{mol}$

(b) $\operatorname{Ir}-\mathrm{B}(1)$

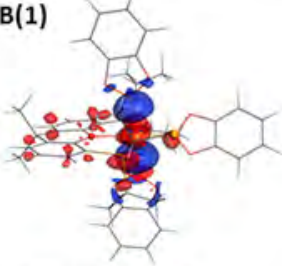

$\Delta E(\sigma)=-86.3 \mathrm{kcal} / \mathrm{mol}$

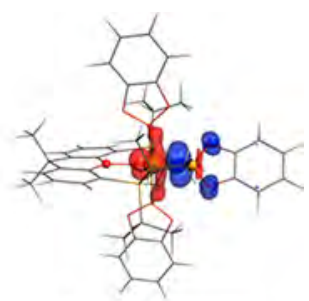

$\Delta E(\pi)=-15.5 \mathrm{kcal} / \mathrm{mol}$

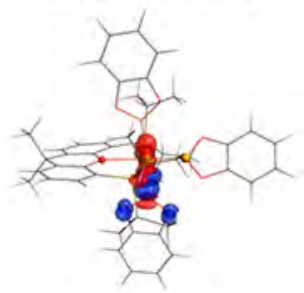

$\Delta E(\pi)=-8.9 \mathrm{kcal} / \mathrm{mol}$

Figure 2. Deformation densities $\Delta \rho$ associated with the strongest pairwise orbital interactions of compound 2 for the $\mathrm{Ir}-\mathrm{B}(2)$ (top) and $\operatorname{Ir}-\mathrm{B}(1)$ (bottom) bonds. The direction of the charge flow is from red to blue.

As expected from the strong trans influence of the boryl ligands, the Bcat groups are disposed mutually cis. This is revealed by the diphosphine resonances in the ${ }^{13} \mathrm{C}\left\{{ }^{1} \mathrm{H}\right\}$ NMR spectrum, which shows two signals at 35.7 and $27.7 \mathrm{ppm}$ for the methyl substituents of the central heterocycle and four signals at 20.3, 19.5, 19.3, and $19.2 \mathrm{ppm}$ for the methyl groups of the isopropyl substituents. The hydride ligand gives rise to a triplet $\left({ }^{2} J_{\mathrm{H}-\mathrm{P}}=21.6 \mathrm{~Hz}\right)$ at $-4.15 \mathrm{ppm}$ in the ${ }^{1} \mathrm{H}$ NMR spectrum, whereas the ${ }^{31} \mathrm{P}\left\{{ }^{1} \mathrm{H}\right\}$ NMR spectrum contains a singlet at $51.2 \mathrm{ppm}$, due to the equivalent $\mathrm{P}^{\mathrm{i}} \mathrm{Pr}_{2}$ groups, that is split into a doublet under off-resonance conditions. A broad resonance centered at $\sim 34.0 \mathrm{ppm}$ in the ${ }^{11} \mathrm{~B}\left\{{ }^{1} \mathrm{H}\right\}$ NMR spectrum for the boryl ligands is another characteristic feature of 4 .

Complex 4 can be also prepared by reaction of 3 with 2.0 equiv of HBcat. The square-planar boryl species $\mathbf{B}$ is also the key intermediate of the process (Scheme S1). In this case, it is formed via $\mathbf{C}$ and the iridium(III)-trans-dihydride $\mathrm{IrH}_{2}$ (Bcat)$\left\{\kappa^{3}-\mathrm{P}, \mathrm{O}, \mathrm{P}-\left[\operatorname{xant}\left(\mathrm{P}^{\mathrm{i}} \mathrm{Pr}_{2}\right)_{2}\right]\right\}(5)$. The latter was characterized in toluene- $d_{8}$ by NMR spectroscopy. Its characteristic features are a triplet $\left({ }^{2} J_{\mathrm{H}-\mathrm{P}}=17.2 \mathrm{~Hz}\right)$ at $-5.57 \mathrm{ppm}$ in the ${ }^{1} \mathrm{H}$ NMR spectrum for the equivalent hydride ligands and a singlet at $60.6 \mathrm{ppm}$ in the ${ }^{31} \mathrm{P}\left\{{ }^{1} \mathrm{H}\right\}$ NMR spectrum, as expected for the equivalent $\mathrm{P}^{\mathrm{i}} \mathrm{Pr}_{2}$ groups of the mer-coordinated etherdiphosphine. This resonance is split into a triplet under offresonance conditions.

Complex 1a also activates the $\mathrm{H}-\mathrm{B}$ bond of HBcat. Thus, the treatment of toluene solutions of its synthetic equivalent 1 with 3.0 equiv of the borane, at room temperature, for $10 \mathrm{~min}$ leads to $\operatorname{IrHCl}(\mathrm{Bcat})\left\{\kappa^{3}-\mathrm{P}, \mathrm{O}, \mathrm{P}-\left[\operatorname{xant}\left(\mathrm{P}^{\mathrm{i}} \mathrm{Pr}_{2}\right)_{2}\right]\right\}$ (6 in Scheme 2 ), as a result of the oxidative addition of the $\mathrm{H}-\mathrm{B}$ bond to the

\section{Scheme 2. Formation of 6}

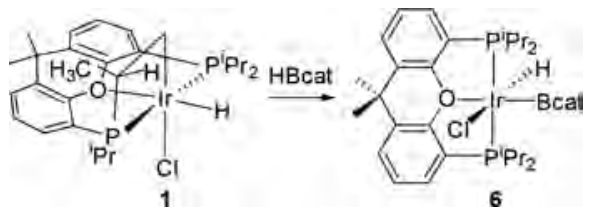

iridium(I) center of $\mathbf{1 a}$. In contrast to $\mathbf{A}$, it is stable toward the reductive elimination of $\mathrm{ClBcat}$. As a consequence, complexes 2-5 cannot be prepared starting from 1 and HBcat. Complex 6 was isolated as a white solid in 67\% yield and was characterized by X-ray diffraction analysis. The structure (Figure S1) shows an octahedral environment around the iridium(III) center with the ether-diphosphine mer-coordinated and the boryl group disposed trans to the oxygen atom. The Ir-B bond length of 1.947 (5) $\AA$ is slightly shorter (0.05$0.06 \AA)$ than the $\operatorname{Ir}-\mathrm{B}(2)$ bond length in 2 . In agreement with the mer coordination of the diphosphine, the ${ }^{31} \mathrm{P}\left\{{ }^{1} \mathrm{H}\right\}$ NMR spectrum displays a singlet at $46.2 \mathrm{ppm}$ due to the equivalent $\mathrm{P}^{\mathrm{i}} \mathrm{Pr}_{2}$ groups. The hydride resonance appears as a triplet $\left({ }^{2} J_{\mathrm{H}-\mathrm{P}}\right.$ $=15.4 \mathrm{~Hz}$ ) at $-19.07 \mathrm{ppm}$ in the ${ }^{1} \mathrm{H}$ NMR spectrum, whereas a broad signal corresponding to the boryl ligand is observed at 36 ppm in the ${ }^{11} \mathrm{~B}\left\{{ }^{1} \mathrm{H}\right\} \mathrm{NMR}$ spectrum.

In summary, complexes $\mathrm{IrHCl}\left\{\kappa^{4}-\mathrm{C}, \mathrm{P}, \mathrm{O}, \mathrm{P}-\left[\mathrm{CH}_{2} \mathrm{CH}\left(\mathrm{CH}_{3}\right)\right.\right.$ $\left.\left.\mathrm{P}\left({ }^{\mathrm{i}} \mathrm{Pr}\right) \operatorname{xant}\left(\mathrm{P}^{\mathrm{i}} \mathrm{Pr}_{2}\right)\right]\right\}$ and $\mathrm{IrH}_{3}\left\{\kappa^{3}-\mathrm{P}, \mathrm{O}, \mathrm{P}-\left[\operatorname{xant}\left(\mathrm{P}^{\mathrm{i}} \mathrm{Pr}_{2}\right)_{2}\right]\right\}$ promote the activation of the $\mathrm{B}-\mathrm{B}$ bond of two molecules of $\mathrm{B}_{2} \mathrm{cat}_{2}$ to give the tris(boryl) derivative $\operatorname{Ir}(\mathrm{Bcat}){ }_{3}\left\{\kappa^{3}-\mathrm{P}, \mathrm{O}, \mathrm{P}-\right.$ $\left.\left[\operatorname{xant}\left(\mathrm{P}^{\mathrm{i}} \mathrm{Pr}_{2}\right)_{2}\right]\right\}$ via bis(boryl) intermediates $\operatorname{IrX}(\mathrm{Bcat})_{2}\left\{\kappa^{3}\right.$ $\left.\mathrm{P}, \mathrm{O}, \mathrm{P}-\left[\operatorname{xant}\left(\mathrm{P}^{\mathrm{i}} \mathrm{Pr}_{2}\right)_{2}\right]\right\}(\mathrm{X}=\mathrm{Cl}$ or $\mathrm{H})$. The tris(boryl) complex displays a mer arrangement of the boryl groups in spite of the very strong trans influene of these ligands. The $\mathrm{Ir}-\mathrm{B}$ bonds disposed mutually trans are $\sim 0.1 \AA$ longer than that disposed cis to the other two. EDA-NOCV analysis of these bonds reveals that the main difference between them is observed in the $\pi$-back-donation from the metal to the $\mathrm{p}_{z}$ atomic orbital of the boron atom, which decreases by $\sim 43 \%$ in the longer bonds with respect to the shorter one, while the level of $\sigma$-bonding interaction diminishes only $\sim 8 \%$. In summary, it is certainly possible to isolate transition metal complexes bearing two boryl ligands disposed mutually trans and to fully characterize them, even through X-ray diffraction analysis, when their coligands are competently selected.

\section{ASSOCIATED CONTENT}

\section{S Supporting Information}

The Supporting Information is available free of charge on the ACS Publications website at DOI: 10.1021/acs.inorgchem.9b00339.

Experimental section, structural analysis, computational details, and NMR spectra (PDF)

\section{Accession Codes}

CCDC 1894567-1894568 contain the supplementary crystallographic data for this paper. These data can be obtained free of charge via www.ccdc.cam.ac.uk/data request/cif, or by emailing data_request@ccdc.cam.ac.uk, or by contacting The Cambridge Crystallographic Data Centre, 12 Union Road, Cambridge CB2 1EZ, UK; fax: +44 1223336033.

\section{AUTHOR INFORMATION}

\section{Corresponding Author}

*E-mail: maester@unizar.es.

\section{ORCID $\odot$}

Miguel A. Esteruelas: 0000-0002-4829-7590

Israel Fernández: 0000-0002-0186-9774

Montserrat Oliván: 0000-0003-0381-0917

Enrique Oñate: 0000-0003-2094-719X

Notes

The authors declare no competing financial interest. 


\section{ACKNOWLEDGMENTS}

Financial support from the MINECO of Spain (Projects CTQ2017-82935-P, CTQ2016-78205-P, Red de Excelencia Consolider CTQ2016-81797-REDC), the Gobierno de Aragón (Group E06_17R and predoctoral contract to A.M.), FEDER, and the European Social Fund is acknowledged.

\section{REFERENCES}

(1) Pidcock, A.; Richards, R. E.; Venanzi, L. M. ${ }^{195} \mathrm{Pt}^{31}{ }^{31}$ P Nuclear Spin Coupling Constants and the Nature of the trans-Effect in Platinum Complexes. J. Chem. Soc. A 1966, 1707-1710.

(2) See, R. F.; Kozina, D. Quantification of the trans influence in $\mathrm{d}^{8}$ square planar and $\mathrm{d}^{6}$ octahedral complexes: a database study. J. Coord. Chem. 2013, 66, 490-500.

(3) (a) Bolaño, T.; Castarlenas, R.; Esteruelas, M. A.; Oñate, E. Sequential and Selective Hydrogenation of the $\mathrm{C}_{\alpha}-\mathrm{C}_{\beta}$ and $\mathrm{M}-\mathrm{C}_{\alpha}$ Double Bonds of an Allenylidene Ligand Coordinated to Osmium: New Reaction Patterns between an Allenylidene Complex and Alcohols. J. Am. Chem. Soc. 2007, 129, 8850-8859. (b) Khoroshun, D. V.; Musaev, D. G.; Morokuma, K. Electronic Recorganization: Origin of Sigma Trans Promotion Effect. J. Comput. Chem. 2007, 28, 423-441. (c) Sajith, P. K.; Suresh, C. H. Quantification of the Trans Influence of Hypervalent Iodine Complexes. Inorg. Chem. 2012, 51, 967-977.

(4) (a) Toledo, J. C.; dos Santos Lima Neto, B.; Franco, D. W. Mutual effects in the chemical properties of the ruthenium metal center and ancillary ligands upon coordination. Coord. Chem. Rev. 2005, 249, 419-431. (b) Sajith, P. K.; Suresh, C. H. Mechanisms of Reductive Elimination in Square Planar Pd(II) Complexes: Nature of Eliminated Bonds and Role of trans Influence. Inorg. Chem. 2011, 50, 8085-8093.

(5) Mitoraj, M. P.; Zhu, H.; Michalak, A.; Ziegler, T. On the Origin of the Trans-Influence in Square Planar $\mathrm{d}^{8}$-Complexes: A Theoretical Study. Int. J. Quantum Chem. 2009, 109, 3379-3386.

(6) Pinter, B.; Van Speybroeck, V.; Waroquier, M.; Geerlings, P.; De Proft, F. trans effect and trans influence: importance of metal mediated ligand-ligand repulsion. Phys. Chem. Chem. Phys. 2013, 15, 17354-17365.

(7) (a) Frenking, G.; Fröhlich, N. The Nature of the Bonding in Transition-Metal Compounds. Chem. Rev. 2000, 100, 717-774. (b) Lam, K. C.; Lam, W. H.; Lin, Z.; Marder, T. B.; Norman, N. C. Structural Analysis of Five-Coordinate Transition Metal Boryl Complexes with Different d-Electron Configurations. Inorg. Chem. 2004, 43, 2541-2547. (c) Zhu, J.; Lin, Z.; Marder, T. B. Trans Influence of Boryl Ligands and Comparison with $\mathrm{C}, \mathrm{Si}$, and $\mathrm{Sn}$ Ligands. Inorg. Chem. 2005, 44, 9384-9390. (d) Braunschweig, H.; Brenner, P.; Müller, A.; Radacki, K.; Rais, D.; Uttinger, K. Experimental Studies on the trans-Influence of Boryl Ligands in Square-Planar Platinum(II) Complexes. Chem. - Eur. J. 2007, 13, 7171-7176. (e) Braunschweig, H.; Damme, A.; Kupfer, T. Evidence for a Strong trans Influence of the Diboran(4)yl Ligand. Chem. - Eur. J. 2012, 18, 15927-15931. (f) Greif, A. H.; Hrobárik, P.; Hrobáriková, V.; Arbuznikov, A. V.; Autschbach, J.; Kaupp, M. A Relativistic Quantum-Chemical Analysis of the trans Influence on ${ }^{1} \mathrm{H}$ NMR Hydride Shifts in Square-Planar Platinum(II) Complexes. Inorg. Chem. 2015, 54, 7199-7208.

(8) (a) Baker, R. T.; Calabrese, J. C.; Westcott, S. A.; Nguyen, P.; Marder, T. B. Insertion of Alkenes into Rh-B Bonds. J. Am. Chem. Soc. 1993, 115, 4367-4368. (b) Iverson, C. N.; Smith, M. R., III Reactivity of Organoplatinum Complexes with $\mathrm{C}_{6} \mathrm{H}_{4} \mathrm{O}_{2} \mathrm{~B}-\mathrm{BO}_{2} \mathrm{C}_{6} \mathrm{H}_{4}$ : Syntheses of a Platinum Diboryl Complex with, and without, Metathesis of Boron-Boron and Metal-Carbon Bonds. J. Am. Chem. Soc. 1995, 117, 4403-4404. (c) He, X.; Hartwig, J. F. Boryls Bound to Iron Carbonyl. Structure of a Rare Bis(boryl) Complex, Synthesis of the First Anionic Boryl, and Reaction Chemistry That Includes the Synthetic Equivalent of Boryl Anion Transfer. Organometallics 1996, 15, 400-407. (d) Ishiyama, T.; Matsuda, N.; Murata, M.; Ozawa, F.; Suzuki, A.; Miyaura, N. Platinum(0)-Catalyzed Diboration of Alkynes with Tetrakis(alkoxo)diborons: An Efficient and Convenient Approach to cis-Bis(boryl)alkenes. Organometallics 1996, 15, 713720. (e) Dai, C.; Stringer, G.; Corrigan, J. F.; Taylor, N. J.; Marder, T. B.; Norman, N. C. Synthesis and molecular structure of the paramagnetic $\mathrm{Co}(\mathrm{II})$ bis(boryl) complex $\left[\mathrm{Co}\left(\mathrm{PMe}_{3}\right)_{3}(\mathrm{Bcat})_{2}\right]$ (cat $\left.=1,2-\mathrm{O}_{2} \mathrm{C}_{6} \mathrm{H}_{4}\right)$. J. Organomet. Chem. 1996, 513, 273-275. (f) Hartwig, J. F.; He, X. Reactivity of Tungstenocene with B-B and B-H Bonds versus C-H Bonds. Angew. Chem., Int. Ed. Engl. 1996, 35, 315-317. (g) Dai, C.; Stringer, G.; Marder, T. B.; Baker, R. T.; Scott, A. J.; Clegg, W.; Norman, N. C. Oxidative addition of a B-B bond by an iridium(I) complex: molecular structure of mer-cis- $\left[\operatorname{lr}\left(\mathrm{PMe}_{3}\right)_{3} \mathrm{Cl}\right.$ (Bcat) ${ }_{2}$ ]. Can. J. Chem. 1996, 74, 2026-2031. (h) Lesley, G.; Nguyen, P.; Taylor, N. J.; Marder, T. B.; Scott, A. J.; Clegg, W.; Norman, N. C. Synthesis and Characterization of Platinum(II)-Bis(boryl) Catalyst Precursors for Diboration of Alkynes and Diynes: Molecular Structures of cis- $\left[\left(\mathrm{PPh}_{3}\right)_{2} \mathrm{Pt}\left(\mathrm{B}-4-\mathrm{Bu} \mathrm{t}^{\mathrm{t}} \mathrm{cat}\right)_{2}\right], \quad$ cis- $\left[\left(\mathrm{PPh}_{3}\right)_{2} \mathrm{Pt}(\mathrm{Bcat})_{2}\right]$, cis- $\left[(\mathrm{dppe}) \mathrm{Pt}(\mathrm{Bcat})_{2}\right], \quad c i s-\left[(\mathrm{dppb}) \mathrm{Pt}(\mathrm{Bcat})_{2}\right], \quad(E)-\left(4-\mathrm{MeOC}_{6} \mathrm{H}_{4}\right) \mathrm{C}$ $(\mathrm{Bcat})=\mathrm{CH}(\mathrm{Bcat}), \quad(\mathrm{Z})-\left(\mathrm{C}_{6} \mathrm{H}_{5}\right) \mathrm{C}(\mathrm{Bcat})=\mathrm{C}\left(\mathrm{C}_{6} \mathrm{H}_{5}\right)(\mathrm{Bcat})$, and $(Z, Z)-\left(4-\mathrm{MeOC}_{6} \mathrm{H}_{4}\right) \mathrm{C}($ Bcat $)=\mathrm{C}($ Bcat $) \mathrm{C}(\mathrm{Bcat})=\mathrm{C}\left(4-\mathrm{MeOC}_{6} \mathrm{H}_{4}\right)$ (Bcat) (cat $=1,2-\mathrm{O}_{2} \mathrm{C}_{6} \mathrm{H}_{4} ;$ dppe $=\mathrm{Ph}_{2} \mathrm{PCH}_{2} \mathrm{CH}_{2} \mathrm{PPh}_{2} ; \mathrm{dppb}=$ $\left.\mathrm{Ph}_{2} \mathrm{P}\left(\mathrm{CH}_{2}\right)_{4} \mathrm{PPh}_{2}\right)$. Organometallics 1996, 15, 5137-5154. (i) Kerr, A.; Marder, T. B.; Norman, N. C.; Orpen, A. G.; Quayle, M. J.; Rice, C. R.; Timms, P. L.; Whittell, G. R. Preparation and structure of cis$\left[\mathrm{Pt}\left(\mathrm{BF}_{2}\right)_{2}\left(\mathrm{PPh}_{3}\right)_{2}\right]$ : the first crystallographically characterised complex containing the $\mathrm{BF}_{2}$ ligand. Chem. Commun. 1998, 319-320. (j) Clegg, W.; Lawlor, F. J.; Lesley, G.; Marder, T. B.; Norman, N. C.; Orpen, A. G.; Quayle, M. J.; Rice, C. R.; Scott, A. J.; Souza, F. E. S. Oxidative addition of boron-boron, boron-chlorine and boronbromine bonds to platinum(0). J. Organomet. Chem. 1998, 550, 183-192. (k) Clegg, W.; Lawlor, F. J.; Marder, T. B.; Nguyen, P.; Norman, N. C.; Orpen, A. G.; Quayle, M. J.; Rice, C. R.; Robins, E. G.; Scott, A. J.; Souza, F. E. S.; Stringer, G.; Whittell, G. R. Boronboron bond oxidative addition to rhodium(I) and iridium(I) Centres. J. Chem. Soc., Dalton Trans. 1998, 301-310. (1) Clegg, W.; Johann, T. R. F.; Marder, T. B.; Norman, N. C.; Orpen, A. G.; Peakman, T. M.; Quayle, M. J.; Rice, C. R.; Scott, A. J. Platinum-catalysed 1,4diboration of 1,3-dienes. J. Chem. Soc., Dalton Trans. 1998, 14311438. (m) Curtis, D.; Lesley, M. J. G.; Norman, N. C.; Orpen, G. A.; Starbuck, J. Phosphine exchange reactions involving cis-[Pt$\left.\left(\mathrm{PPh}_{3}\right)_{2}(\mathrm{Bcat})_{2}\right]\left(\right.$ cat $\left.=1,2-\mathrm{O}_{2} \mathrm{C}_{6} \mathrm{H}_{4}\right)$ and the oxidative addition of 1,2- $\mathrm{B}_{2} \mathrm{Cl}_{2}\left(\mathrm{NMe}_{2}\right)_{2}$ to $\mathrm{Pt}^{0}$. J. Chem. Soc., Dalton Trans. 1999, 16871694. (n) Lantero, D. R.; Miller, S. L.; Cho, J.-Y.; Ward, D. L.; Smith, M. R., III A Mechanistic Dichotomy in the Reactions of $\mathrm{Cp}_{2} \mathrm{M}$ $\left(\mathrm{CH}_{2}=\mathrm{CHMe}\right)(\mathrm{M}=\mathrm{Nb}, \mathrm{Ta})$ with Catecholborane: Generation of Boryl Complexes by Propylene Hydroboration and Propylene Loss. Organometallics 1999, 18, 235-247. (o) Rickard, C. E. F.; Roper, W. R.; Williamson, A.; Wright, L. J. Reactions of cis and trans Bcat, Aryl Osmium Complexes (cat $\left.=1,2-\mathrm{O}_{2} \mathrm{C}_{6} \mathrm{H}_{4}\right)$. Bis (Bcat) Complexes of Osmium and Ruthenium and a Structural Comparison of cis and trans Isomers of $\mathrm{Os}(\mathrm{Bcat}) \mathrm{I}(\mathrm{CO})_{2}\left(\mathrm{PPh}_{3}\right)_{2}$. Organometallics 2000, 19, 43444355. (p) Adams, C. J.; Baber, R. A.; Batsanov, A. S.; Bramham, G.; Charmant, J. P. H.; Haddow, M. F.; Howard, J. A. K.; Lam, W. H.; Lin, Z.; Marder, T. B.; Norman, N. C.; Orpen, A. G. Synthesis and reactivity of cobalt boryl complexes. Dalton Trans 2006, 1370-1373. (q) Charmant, J. P. H.; Fan, C.; Norman, N. C.; Pringle, P. G. Synthesis and reactivity of dichloroboryl complexes of platinum(II). Dalton Trans 2007, 114-123. (r) Braunschweig, H.; Bertermann, R.; Brenner, P.; Burzler, M.; Dewhurst, R. D.; Radacki, K.; Seeler, F. trans- $\left[\mathrm{Pt}\left(\mathrm{BCat}{ }^{\prime}\right) \mathrm{Me}\left(\mathrm{PCy}_{3}\right)_{2}\right]:$ An Experimental Case Study of Reductive Elimination Processes in Pt-Boryls through Associative Mechanisms. Chem. - Eur. J. 2011, 17, 11828-11837. (s) Esteruelas, M. A.; Fernández, I.; López, A. M.; Mora, M.; Oñate, E. Preparation, Structure, Bonding, and Preliminary Reactivity of a Six-Coordinate $\mathrm{d}^{4}$ Osmium-Boryl Complex. Organometallics 2012, 31, 4646-4649. (t) Braunschweig, H.; Brenner, P.; Dewhurst, R. D.; Guethlein, F.; Jimenez-Halla, J. O. C.; Radacki, K.; Wolf, J.; Zöllner, L. Observation of Elementary Steps in the Catalytic Borane Dehydrocoupling Reaction. Chem. - Eur. J. 2012, 18, 8605-8609. (u) Braunschweig, H.; Damme, A. Thermodynamic control of oxidative addition and 
reductive elimination processes in cis-bis(dimethoxyboryl)-bis(tricyclohexylphosphine)platinum(II). Chem. Commun. 2013, 49, 5216-5218. (v) Braunschweig, H.; Damme, A.; Kupfer, T. Conversion of trans-Diboran(4)yl Platinum Complexes into Their cis-Bisboryl Analogues. Chem. - Eur. J. 2013, 19, 14682-14686. (w) Lee, C.-I.; Zhou, J.; Ozerov, O. V. Catalytic Dehydrogenative Borylation of Terminal Alkynes by a SiNN Pincer Complex of Iridium. J. Am. Chem. Soc. 2013, 135, 3560-3566. (x) Schubert, H.; Leis, W.; Mayer, H. A.; Wesemann, L. A bidentate boryl ligand: syntheses of platinum and iridium complexes. Chem. Commun. 2014, 50, 2738-2740. (y) Borner, C.; Kleeberg, C. Selective Synthesis of Unsymmetrical Diboryl $\mathrm{Pt}^{\mathrm{II}}$ and Diaminoboryl $\mathrm{Cu}^{\mathrm{I}}$ Complexes by $\mathrm{B}-$ B Activation of Unsymmetrical Diboranes(4) \{pinB-B $\left.\left[(\mathrm{NR})_{2} \mathrm{C}_{6} \mathrm{H}_{4}\right]\right\}$. Eur. J. Inorg. Chem. 2014, 2014, 2486-2489. (z) Wang, G.; Xu, L.; Li, P. Double N,B-Type Bidentate Boryl Ligands Enabling a Highly Active Iridium Catalyst for C-H Borylation. J. Am. Chem. Soc. 2015, 137, 8058-8061. (aa) Larsen, M. A.; Wilson, C. V.; Hartwig, J. F. Iridium-Catalyzed Borylation of Primary Benzylic C-H Bonds without a Directing Group: Scope, Mechanism, and Origins of Selectivity. J. Am. Chem. Soc. 2015, 137, 8633-8643. (ab) Lee, C.-I.; DeMott, J. C.; Pell, C. J.; Christopher, A.; Zhou, J.; Bhuvanesh, N.; Ozerov, O. V. Ligand survey results in identification of PNP pincer complexes of iridium as long-lived and chemoselective catalysts for dehydrogenative borylation of terminal alkynes. Chem. Sci. 2015, 6, 6572-6582. (ac) Press, L. P.; Kosanovich, A. J.; McCulloch, B. J.; Ozerov, O. V. High-Turnover Aromatic C-H Borylation Catalyzed by POCOP-Type Pincer Complexes of Iridium. J. Am. Chem. Soc. 2016, 138, 94879497.

(9) (a) Nguyen, P.; Blom, H. P.; Westcott, S. A.; Taylor, N. J.; Marder, T. B. Synthesis and Structures of the First Transition-Metal Tris(boryl) Complexes: ( $\eta^{6}$-Arene $) \operatorname{Ir}\left(\mathrm{BO}_{2} \mathrm{C}_{6} \mathrm{H}_{4}\right)_{3}$. J. Am. Chem. Soc. 1993, 115, 9329-9330. (b) Dai, C.; Stringer, G.; Marder, T. B.; Scott, A. J.; Clegg, W.; Norman, N. C. Synthesis and Characterization of Rhodium(I) Boryl and Rhodium(III) Tris(Boryl) Compounds: Molecular Structures of $\left[\left(\mathrm{PMe}_{3}\right)_{4} \mathrm{Rh}(\mathrm{B}(\mathrm{cat}))\right]$ and $\mathrm{fac}-\left[\left(\mathrm{PMe}_{3}\right)_{3} \mathrm{Rh}-\right.$ $\left.(\mathrm{B}(\mathrm{cat}))_{3}\right]\left(\right.$ cat $\left.=1,2-\mathrm{O}_{2} \mathrm{C}_{6} \mathrm{H}_{4}\right)$. Inorg. Chem. 1997, 36, 272-273. (c) Lu, N.; Norman, N. C.; Orpen, G.; Quayle, M. J.; Timms, P. L.; Whittell, G. R. Transition metal complexes incorporating the $\mathrm{BF}_{2}$ ligand formed by oxidative addition of the $\mathrm{B}-\mathrm{B}$ bond in $\mathrm{B}_{2} \mathrm{~F}_{4}$. J. Chem. Soc., Dalton Trans. 2000, 4032-4037. (d) Ishiyama, T.; Takagi, J.; Ishida, K.; Miyaura, N.; Anastasi, N. R.; Hartwig, J. F. Mild IridiumCatalyzed Borylation of Arenes. High Turnover Numbers, Room Temperature Reactions, and Isolation of a Potential Intermediate. J. Am. Chem. Soc. 2002, 124, 390-391. (e) Hartwig, J. F.; Cook, K. S.; Hapke, M.; Incarvito, C. D.; Fan, Y.; Webster, C. E.; Hall, M. B. Rhodium Boryl Complexes in the Catalytic, Terminal Functionalization of Alkanes. J. Am. Chem. Soc. 2005, 127, 2538-2552. (f) Liskey, C. W.; Wei, C. S.; Pahls, D. L.; Hartwig, J. F. Pronounced effects of substituents on the iridium-catalyzed borylation of aryl C-H bonds. Chem. Commun. 2009, 5603-5605. (g) Chotana, G. A.; Vanchura, B. A., II; Tse, M. K.; Staples, R. J.; Maleczka, R. E., Jr.; Smith, M. R., III Getting the sterics just right: a five-coordinate iridium trisboryl complex that reacts with $\mathrm{C}-\mathrm{H}$ bonds at room temperature. Chem. Commun. 2009, 5731-5733. (h) Vanchura, B. A., II; Preshlock, S. M.; Roosen, P. C.; Kallepalli, V. A.; Staples, R. J.; Maleczka, R. E., Jr.; Singleton, D. A.; Smith, M. R., III. Electronic effects in iridium C-H borylations: insights from unencumbered substrates and variation of boryl ligand substituents. Chem. Commun. 2010, 46, 7724-7726. (i) Ghaffari, B.; Vanchura, B. A., II; Chotana, G. A.; Staples, R. J.; Holmes, D.; Maleczka, R. E., Jr.; Smith, M. R., III Reversible Borylene Formation from Ring Opening of Pinacolborane and Other Intermediates Generated from Five-Coordinate Tris-Boryl Complexes: Implications for Catalytic C-H Borylation. Organometallics 2015, 34, 4732-4740.

(10) (a) Kajiwara, T.; Terabayashi, T.; Yamashita, M.; Nozaki, K. Syntheses, Structures, and Reactivities of Borylcopper and -zinc Compounds: 1,4 -Silaboration of an $\alpha, \beta$-Unsaturated Ketone to Form a $\gamma$-Siloxyallylborane. Angew. Chem., Int. Ed. 2008, 47, 6606-6610. (b) Protchenko, A. V.; Dange, D.; Schwarz, A. D.; Tang, C. Y.;
Phillips, N.; Mountford, P.; Jones, C.; Aldridge, S. Heavy metal boryl chemistry: complexes of cadmium, mercury and lead. Chem. Commun. 2014, 50, 3841-3844.

(11) See for example: (a) van der Veen, L. A.; Keeven, P. H.; Schoemaker, G. C.; Reek, J. N. H.; Kamer, P. C. J.; van Leeuwen, P. W. N. M.; Lutz, M.; Spek, A. L. Origin of the Bite Angle Effect on Rhodium Diphosphine Catalyzed Hydroformylation. Organometallics 2000, 19, 872-883. (b) Johns, A. M.; Utsunomiya, M.; Incarvito, C. D.; Hartwig, J. F. A Highly Active Palladium Catalyst for Intermolecular Hydroamination. Factors that Control Reactivity and Additions of Functionalized Anilines to Dienes and Vinylarenes. J. Am. Chem. Soc. 2006, 128, 1828-1839. (c) Grushin, V. V.; Marshall, W. J. Facile $\mathrm{Ar}-\mathrm{CF}_{3}$ Bond Formation at Pd. Strikingly Different Outcomes of Reductive Elimination from $\left[\left(\mathrm{Ph}_{3} \mathrm{P}\right)_{2} \mathrm{Pd}\left(\mathrm{CF}_{3}\right) \mathrm{Ph}\right]$ and [(Xantphos) $\mathrm{Pd}\left(\mathrm{CF}_{3}\right) \mathrm{Ph}$ ]. J. Am. Chem. Soc. 2006, 128, 1264412645. (d) Ledger, A. E. W.; Mahon, M. F.; Whittlesey, M. K.; Williams, J. M. J. $\left[\mathrm{Ru}(\mathrm{NHC})(\right.$ xantphos $\left.)(\mathrm{CO}) \mathrm{H}_{2}\right]$ complexes: intramolecular $\mathrm{C}-\mathrm{H}$ activation and applications in $\mathrm{C}-\mathrm{C}$ bond formation. Dalton Trans 2009, 6941-6947. (e) Grutters, M. M. P.; van der Vlugt, J. I.; Pei, Y.; Mills, A. M.; Lutz, M.; Spek, A. L.; Müller, C.; Moberg, C.; Vogt, D. Highly Selective Cobalt-Catalyzed Hydrovinylation of Styrene. Adv. Synth. Catal. 2009, 351, 2199-2208. (f) Staudaher, N. D.; Stolley, R. M.; Louie, J. Synthesis, mechanism of formation, and catalytic activity of Xantphos nickel $\pi$-complexes. Chem. Commun. 2014, 50, 15577-15580.

(12) See for example: (a) Kuang, S.-M.; Cuttell, D. G.; McMillin, D. R.; Fanwick, P. E.; Walton, R. A. Synthesis and Structural Characterization of $\mathrm{Cu}(\mathrm{I})$ and $\mathrm{Ni}(\mathrm{II})$ Complexes that Contain the Bis[2-(diphenylphosphino)phenyl] ether Ligand. Novel Emission Properties for the $\mathrm{Cu}(\mathrm{I})$ Species. Inorg. Chem. 2002, 41, 33133322. (b) Moxham, G. L.; Randell-Sly, H. E.; Brayshaw, S. K.; Woodward, R. L.; Weller, A. S.; Willis, M. C. A Second-Generation Catalyst for Intermolecular Hydroacylation of Alkenes and Alkynes Using $\beta$-S-Substituted Aldehydes: The Role of a Hemilabile P-O-P Ligand. Angew. Chem., Int. Ed. 2006, 45, 7618-7622. (c) Venkateswaran, R.; Mague, J. T.; Balakrishna, M. S. Ruthenium(II) Complexes Containing Bis(2-(diphenylphosphino)phenyl) Ether and Their Catalytic Activity in Hydrogenation Reactions. Inorg. Chem. 2007, 46, 809-817. (d) Moxham, G. L.; Randell-Sly, H.; Brayshaw, S. K.; Weller, A. S.; Willis, M. C. Intermolecular Alkene and Alkyne Hydroacylation with $\beta$-S-Substituted Aldehydes: Mechanistic Insight into the Role of a Hemilabile P-O-P Ligand. Chem. - Eur. J. 2008, 14, 8383-8397. (e) Czerwieniec, R.; Yu, J.; Yersin, H. Blue-Light Emission of $\mathrm{Cu}(\mathrm{I})$ Complexes and Singlet Harvesting. Inorg. Chem. 2011, 50, 8293-8301. (f) Baumann, W.; Spannenberg, A.; Pfeffer, J.; Haas, T.; Köckritz, A.; Martin, A.; Deutsch, J. Utilization of Common Ligands for the Ruthenium-Catalyzed Amination of Alcohols. Chem. Eur. J. 2013, 19, 17702-17706. (g) Chen, H.; Zhou, H.; Zhang, K.; Li, J.; Huang, H. Highly Enantioselective Hydrogenation of Steric Hindrance Enones Catalyzed by Ru Complexes with Chiral Diamine and Achiral Phosphane. Org. Lett. 2014, 16, 3912-3915. (h) Pingen, D.; Lebl, T.; Lutz, M.; Nichol, G. S.; Kamer, P. C. J.; Vogt, D. Catalytic Activity and Fluxional Behavior of Complexes Based on $\mathrm{RuHCl}(\mathrm{CO})\left(\mathrm{PPh}_{3}\right)_{3}$ and Xantphos-Type Ligands. Organometallics 2014, 33, 2798-2805. (i) Linfoot, C. L.; Leitl, M. J.; Richardson, P.; Rausch, A. F.; Chepelin, O.; White, F. J.; Yersin, H.; Robertson, N. Thermally Activated Delayed Fluorescence (TADF) and Enhancing Photoluminescence Quantum Yields of [CuI(diimine)(diphosphine) $]^{+}$Complexes-Photophysical, Structural, and Computational Studies. Inorg. Chem. 2014, 53, 10854-10861. (j) Gellrich, U.; Mei $\beta$ ner, A.; Steffani, A.; Kähny, M.; Drexler, H.-J.; Heller, D.; Plattner, D. A.; Breit, B. Mechanistic Investigations of the Rhodium Catalyzed Propargylic CH Activation. J. Am. Chem. Soc. 2014, 136, 1097-1104. (k) Ensign, S. C.; Vanable, E. P.; Kortman, G. D.; Weir, L. J.; Hull, K. L. Anti-Markovnikov Hydroamination of Homoallylic Amines. J. Am. Chem. Soc. 2015, 137, 13748-13751.

(13) (a) Asensio, G.; Cuenca, A. B.; Esteruelas, M. A.; MedioSimón, M.; Oliván, M.; Valencia, M. Osmium(III) Complexes with POP Pincer Ligands: Preparation from Commercially Available 
$\mathrm{OsCl}_{3} \cdot 3 \mathrm{H}_{2} \mathrm{O}$ and Their X-ray Structures. Inorg. Chem. 2010, 49, 8665-8667. (b) Esteruelas, M. A.; Oliván, M.; Vélez, A. XantphosType Complexes of Group 9: Rhodium versus Iridium. Inorg. Chem. 2013, 52, 5339-5349. (c) Esteruelas, M. A.; Oliván, M.; Vélez, A. POP-Pincer Silyl Complexes of Group 9: Rhodium versus Iridium. Inorg. Chem. 2013, 52, 12108-12119. (d) Alós, J.; Bolaño, T.; Esteruelas, M. A.; Oliván, M.; Oñate, E.; Valencia, M. POP-Pincer Ruthenium Complexes: $\mathrm{d}^{6}$ Counterparts of Osmium $\mathrm{d}^{4}$ Species. Inorg. Chem. 2014, 53, 1195-1209. (e) Esteruelas, M. A.; Oliván, M.; Vélez, A. POP-Rhodium-Promoted C-H and B-H Bond Activation and C-B Bond Formation. Organometallics 2015, 34, 1911-1924. (f) Esteruelas, M. A.; Oliván, M.; Vélez, A. Conclusive Evidence on the Mechanism of the Rhodium-Mediated Decyanative Borylation. J. Am. Chem. Soc. 2015, 137, 12321-12329. (g) Alós, J.; Esteruelas, M. A.; Oliván, M.; Oñate, E.; Puylaert, P. C-H Bond Activation Reactions in Ketones and Aldehydes Promoted by POP-Pincer Osmium and Ruthenium Complexes. Organometallics 2015, 34, 4908-4921. (h) Curto, S. G.; Esteruelas, M. A.; Oliván, M.; Oñate, E.; Vélez, A. Selective C-Cl Bond Oxidative Addition of Chloroarenes to a POPRhodium Complex. Organometallics 2017, 36, 114-128. (i) Esteruelas, M. A.; Fernández, I.; García-Yebra, C.; Martín, J.; Oñate, E. Elongated $\sigma$-Borane versus $\sigma$-Borane in Pincer-POP-Osmium Complexes. Organometallics 2017, 36, 2298-2307. (j) Curto, S. G.; Esteruelas, M. A.; Oliván, M.; Oñate, E.; Vélez, A. $\beta$-Borylalkenyl Z-E Isomerization in Rhodium-Mediated Diboration of Nonfunctionalized Internal Alkynes. Organometallics 2018, 37, 1970-1978. (k) Esteruelas, M. A.; García-Yebra, C.; Martín, J.; Oñate, E. Dehydrogenation of Formic Acid Promoted by a Trihydride-Hydroxo-Osmium(IV) Complex: Kinetics and Mechanism. ACS Catal. 2018, 8, 1131411323.

(14) (a) Bakhmutov, V. I.; Bozoglian, F.; Gómez, K.; González, G.; Grushin, V. V.; Macgregor, S. A.; Martin, E.; Miloserdov, F. M.; Novikov, M. A.; Panetier, J. A.; Romashov, L. V. $\mathrm{CF}_{3}$-Ph Reductive Elimination from [(Xantphos) $\left.\mathrm{Pd}\left(\mathrm{CF}_{3}\right)(\mathrm{Ph})\right]$. Organometallics 2012, 31, 1315-1328. (b) Alós, J.; Bolaño, T.; Esteruelas, M. A.; Oliván, M.; Oñate, E.; Valencia, M. POP-Pincer Osmium-Polyhydrides: Head-toHead (Z)-Dimerization of Terminal Alkynes. Inorg. Chem. 2013, 52, 6199-6213. (c) Jover, J.; Miloserdov, F. M.; Benet-Buchholz, J.; Grushin, V. V.; Maseras, F. On the Feasibility of Nickel-Catalyzed Trifluoromethylation of Aryl Halides. Organometallics 2014, 33, 6531-6543. (d) Esteruelas, M. A.; Nolis, P.; Oliván, M.; Oñate, E.; Vallribera, A.; Vélez, A. Ammonia Borane Dehydrogenation Promoted by a Pincer-Square-Planar Rhodium(I) Monohydride: A Stepwise Hydrogen Transfer from the Substrate to the Catalyst. Inorg. Chem. 2016, 55, 7176-7181. (e) Esteruelas, M. A.; García-Yebra, C.; Martín, J.; Oñate, E. mer, fac, and Bidentate Coordination of an AlkylPOP Ligand in the Chemistry of Nonclassical Osmium Hydrides. Inorg. Chem. 2017, 56, 676-683. (f) Antiñolo, A.; Esteruelas, M. A.; García-Yebra, C.; Martín, J.; Oñate, E.; Ramos, A. Reactions of an Osmium(IV)-Hydroxo Complex with Amino-Boranes: Formation of Boroxide Derivatives. Organometallics 2019, 38, 310-318.

(15) See computational details in the Supporting Information.

(16) See for instance: (a) Wu, Z.; Xu, J.; Sokolenko, L.; Yagupolskii, Y. L.; Feng, R.; Liu, Q.; Lu, Y.; Zhao, L.; Fernández, I.; Frenking, G.; Trabelsi, T.; Francisco, J. S.; Zeng, X. Parent Thioketene S-Oxide $\mathrm{H}_{2} \mathrm{CCSO}$ : Gas-Phase Generation, Structure, and Bonding Analysis. Chem. - Eur. J. 2017, 23, 16566-16573. (b) Hermann, M.; Frenking, G. Carbones as Ligands in Novel Main-Group Compounds $\mathrm{E}\left[\mathrm{C}(\mathrm{NHC})_{2}\right] 2\left(\mathrm{E}=\mathrm{Be}, \mathrm{B}^{+}, \mathrm{C}^{2+}, \mathrm{N}^{3+}, \mathrm{Mg}, \mathrm{Al}^{+}, \mathrm{Si}^{2+}, \mathrm{P}^{3+}\right): \mathrm{A}$ Theoretical Study. Chem. - Eur. J. 2017, 23, 3347-3356. (c) Foroutan-Nejad, C.; Straka, M.; Fernández, I.; Frenking, G. Buckyball Difluoride $\mathrm{F}_{2}^{-} @ \mathrm{C}_{60}{ }^{+}$- A Single-Molecule Crystal. Angew. Chem., Int. Ed. 2018, 57, 13931-13934.

(17) A similar result has been found for a related compound having an Os-B bond. See: Buil, M. L.; Cardo, J. J. F.; Esteruelas, M. A.; Fernández, I.; Oñate, E. Unprecedented Addition of Tetrahydroborate to an Osmium-Carbon Triple Bond. Organometallics 2014, 33, $2689-2692$.
(18) Esteruelas, M. A.; López, A. M.; Oliván, M. Polyhydrides of Platinum Group Metals: Nonclassical Interactions and $\sigma$-Bond Activation Reactions. Chem. Rev. 2016, 116, 8770-8847. 